\title{
Vacunas y COVID-19 en el siglo XXI
}

\section{Vaccines and COVID-19 in the XXI century}

\author{
Jorge Jiménez de la Jara ${ }^{1}$, Jaime Cerda Lorca ${ }^{1}$
}

Palabras clave: vacunas; Chile; inmunización; historia, prevención.

Una de las explosiones más notables que ha ocurrido en el último año, el 2020 del siglo XXI, es la preocupación y debate sobre las vacunas para controlar la pandemia del nuevo virus SARS-CoV-2 al cumplirse un año de iniciada. Sobre esta pandemia ya se han escrito miles de comunicaciones científicas y de divulgación, incluyendo las de carácter puramente políticas o apocalípticas. A los millones de casos diagnosticados en el planeta, con sus dos millones de fallecidos, se une al cumplirse doce meses de este breve y devastador fenómeno la iniciación del proceso vacunatorio, que abre la esperanza de salir de la inmensa enfermedad cuanto antes.

El uso de las vacunas como instrumento de prevención y protección es un hecho social y sanitario relativamente reciente. La fecha utilizada como marcadora de inicio de la práctica es 1796, cuando el médico inglés Edward Jenner (1749-1823) vacunó contra la viruela al niño James Phipps, en la Inglaterra previctoriana. Algunos años antes Benjamín Franklin (1706-1790), después de la trágica muerte de uno de sus hijos a causa de la viruela, creó la "Society for Innoculating the Poor Gratis". Con el sólo título de esta suerte de ONG definió la conveniencia de variolizar a los pobres sin cobrar, tres elementos de validez presente: movilización social con la eficacia de la vacuna, preferencia por los desposeídos y gratuidad (nótese que la variolización corresponde a un proceso preventivo alternativo y muy anterior al advenimiento de la vacunación propiamente tal). La primera vacuna contra la viruela motivó, en los albores del siglo XIX, lo que es considerado por la historia como la primera gran fuerza de tarea de alcance global, conocida como la "Real expedición filantrópica de la vacuna", iniciativa patrocinada por el monarca español Carlos IV (1748-1819) y ejecutada admirablemente por el médico alicantino Francisco Javier Balmis (1753-1819) y su mano derecha, el Dr. José Salvany y Lleopart (1778-1810), quienes ingeniosamente transportaron la vacuna desde Europa hacia América, permitiendo su distribución y la creación de numerosas "juntas de vacunación" en el Nuevo Mundo (Asensi, 2009). Un brazo de la "Expedición Balmis" logró llegar tan lejos como nuestro país, de la mano del Dr. Manuel Julián Grajales (nac. 1775) (Laval, 2014).

La viruela se erradicó en el planeta dos siglos después, en 1976, en un esfuerzo global de la Organización Mundial de la Salud con características épicas, encabezado por el inigualable salubrista de Johns Hopkins, Donald A. Henderson (1928-2016). En nuestro país la primera gran discusión pública ocurrió cuando el presidente José Manuel Balmaceda (1840-1891) estableció la obligatoriedad de la vacunación el año 1886, idea promovida y defendida con pasión por el diputado y médico Dr. Adolfo Murillo (1840-1899). Después de grandes campañas, la erradicación ocurrió en 1956, un par de décadas antes que el control universal.

La creación de las instituciones de medicina social y su brazo preventivo fueron controlando progresivamente entre otras infecciones, tales como difteria, tos convulsiva o coqueluche, poliomielitis y finalmente el sarampión. Sobre el sarampión, virus respiratorio con exantema, vale la pena comentar que, siendo la infección que mayor mortalidad infantil provocaba, entre el uso e introducción de la vacuna en Chile trascurrieron treinta años. Primero disminuyó fuertemente la mortalidad, después los brotes se hicieron menos frecuentes y finalmente la instauración de una segunda dosis logró el control de la circulación comunitaria y erradicación del sarampión en Chile. En otras palabras, las vacunas, siendo efectivas y pro-equidad, no son milagrosas o instantáneas y requieren de una logística poderosa (Jiménez,1995).

(1) Departamento de Salud Pública. Facultad de Medicina, Pontificia Universidad Católica de Chile. 


\section{¿Qué se puede decir del COVID-19 y sus vacunas?}

La ocurrencia de epidemias ha sido una constante a lo largo de la historia, con su cortejo de miedo, muerte y sufrimiento. La historia es cíclica y hoy nuevamente enfrentamos una pandemia, la más grave de los últimos 100 años. Volvemos a sentir el temor que tantas veces sintieron nuestros antepasados; sin embargo, corremos con cierta ventaja: los conocimientos científicos y el desarrollo tecnológico de los últimos 50 años no tienen parangón con otras épocas. Los avances de la microbiología y biología molecular nos han permitido conocer la secuencia génica del SARS-CoV-2, su estructura y la forma en que opera en células del cuerpo humano. Los modelos matemáticos, por su parte, nos han permitido entender de mejor forma la dinámica de circulación virus a nivel de la población. Diversos expertos en epidemiología y salud pública han liderado y/o brindado asesoría a los tomadores de decisiones en torno al establecimiento de medidas preventivas de contagio, tanto de nivel individual (ej. uso de mascarillas, lavado de manos) como poblacional (ej. establecimiento de cuarentenas), y actividades de vigilancia epidemiológica. Todo esto ocurre en el contexto de un mundo globalizado, en el cual los diferentes países disponen de información inmediata sobre el avance de la pandemia en otros países, compartiendo tanto experiencias exitosas como fracasos.

Posiblemente el punto que más interés ha generado en la comunidad científica y en el público en general es la celeridad con que diversas universidades y laboratorios alrededor del mundo han creado diferentes prototipos de vacunas, con la esperanza que su aplicación masiva permita controlar la pandemia. En la actualidad, un conjunto de vacunas están siendo evaluadas mediante estudios clínicos de fase 3, los cuales intentan descifrar la eficacia y seguridad de la vacuna, previo a su administración a grandes grupos humanos. Nuestro país no ha sido ajeno a estos esfuerzos internacionales, ya que numerosos profesionales han aportado su conocimiento práctico para la realización de los mencionados estudios, cuyo conocimiento tendrá una repercusión universal. Superados estos difíciles momentos, podremos decir con orgullo que Chile no se restó del desafío planetario, correspondiéndole también un lugar en la historia.

Finalizamos estas palabras señalando la importancia que tiene en el control de la pandemia el compromiso que todas las personas tenemos con los demás, adhiriendo con constancia a la aplicación de las medidas generales para reducir el contagio y, cuando dispongamos de un conjunto de vacunas eficaces y seguras, disponiéndonos a recibirlas. Confiamos en que todos juntos, con un gran sentido comunitario y del deber, lograremos superar estos difíciles momentos.

\section{Referencias}

Asensi Botet F. (2009). La real expedición filantrópica de la vacuna (Xavier de Balmis/Josep Salvany): 1803-1806. Rev. chil. infectol. 26, 562-567.

Jiménez J. (1995). Control del sarampión en Chile, Dolmen Ediciones. Santiago.

Laval E. (2014). Manuel Julián Grajales: Propagador de la vacuna antivariólica en América del Sur. Anatomista y cirujano. Rev. chil. infectol. 31,743-745. 